\title{
AVANCES CIENTÍFICOS EN LAS ESTRATEGIAS TERAPÉUTICAS CONTRA LA ENFERMEDAD POR VIRUS DEL ÉBOLA
}

Sandra Zapata ${ }^{1}$

Carlos Moneriz ${ }^{2}$

\section{RESUMEN}

La enfermedad por el virus del Ébola se conoce desde hace treinta años como mortal, contagiosa y de difícil diagnóstico y tratamiento. Numerosos estudios se han realizado para comprender la patogénesis del virus y con ello los posibles tratamientos que puedan generar control de la enfermedad. Sin embargo, no hay hasta la fecha un fármaco o vacuna con licencia para combatir el virus del Ébola. El tratamiento está basado solo en aliviar los síntomas y prevenir el contagio por medio de acciones que ayuden a minimizar el riesgo de infección. En esta revisión, se presentan las diferentes perspectivas del estado actual de la investigación sobre fármacos antivirales y vacunas en fases de desarrollo para la infección del virus del Ébola.

Palabras clave: Virus del Ébola, enfermedad por virus del Ébola, antiviral, vacunas.

\section{SCIENTIFIC ADVANCES IN THERAPEUTIC STRATEGIES AGAINST DISEASE BY EBOLA VIRUS \\ ABSTRACT}

Ebola virus disease has been known for thirty years as a lethal, contagious and difficult to diagnose and treat disease. Numerous studies have been conducted to understand the pathogenesis of the virus and thus the possible treatments that may promote disease control. However, to date there is no licensed vaccine or medicine to fight Ebola virus. The treatment is based only on relieving symptoms and preventing contagion through actions that help minimize the risk of infection. This review presents different perspectives of the current state of research on antiviral medicine and vaccines in development stages for Ebola virus infection.

Key words: Ebola virus, Ebola virus disease, antiviral, vaccines.

\footnotetext{
${ }^{1}$ Bsc. Grupo Bioquímica y Enfermedad. Facultad de Medicina, Universidad de Cartagena (Colombia). sandramarce24@ hotmail.com

2 PhD. Grupo Bioquímica y Enfermedad. Facultad de Medicina, Universidad de Cartagena (Colombia). cmonerizp@ unicartagena.edu.co
} 


\section{INTRODUCCIÓN}

La enfermedad por el virus del Ébola (EVE) es una enfermedad contagiosa muy grave causante de brotes con fiebre hemorrágica aguda y de gran mortalidad en humanos y en primates no humanos (NHP, del inglés Non Human Primates), producida por un filovirus con ARN monocatenario de polaridad negativa, morfología filamentosa y pleomórfica y simetría helicoidal (1), cuyo genoma viral codifica proteínas estructurales que permiten la gemación del virus e inhabilitan la respuesta inmune del huésped (VP24, VP30, VP35 Y VP40) (2) y proteínas no estructurales que participan en la inmunoevasión del virus (nucleoproteínas y glucoproteínas) (3). El ciclo de replicación del virus del Ébola (Figura 1), ha ofrecido un buen punto de partida para la identificación de posibles blancos terapéuticos en el desarrollo de compuestos antivirales.

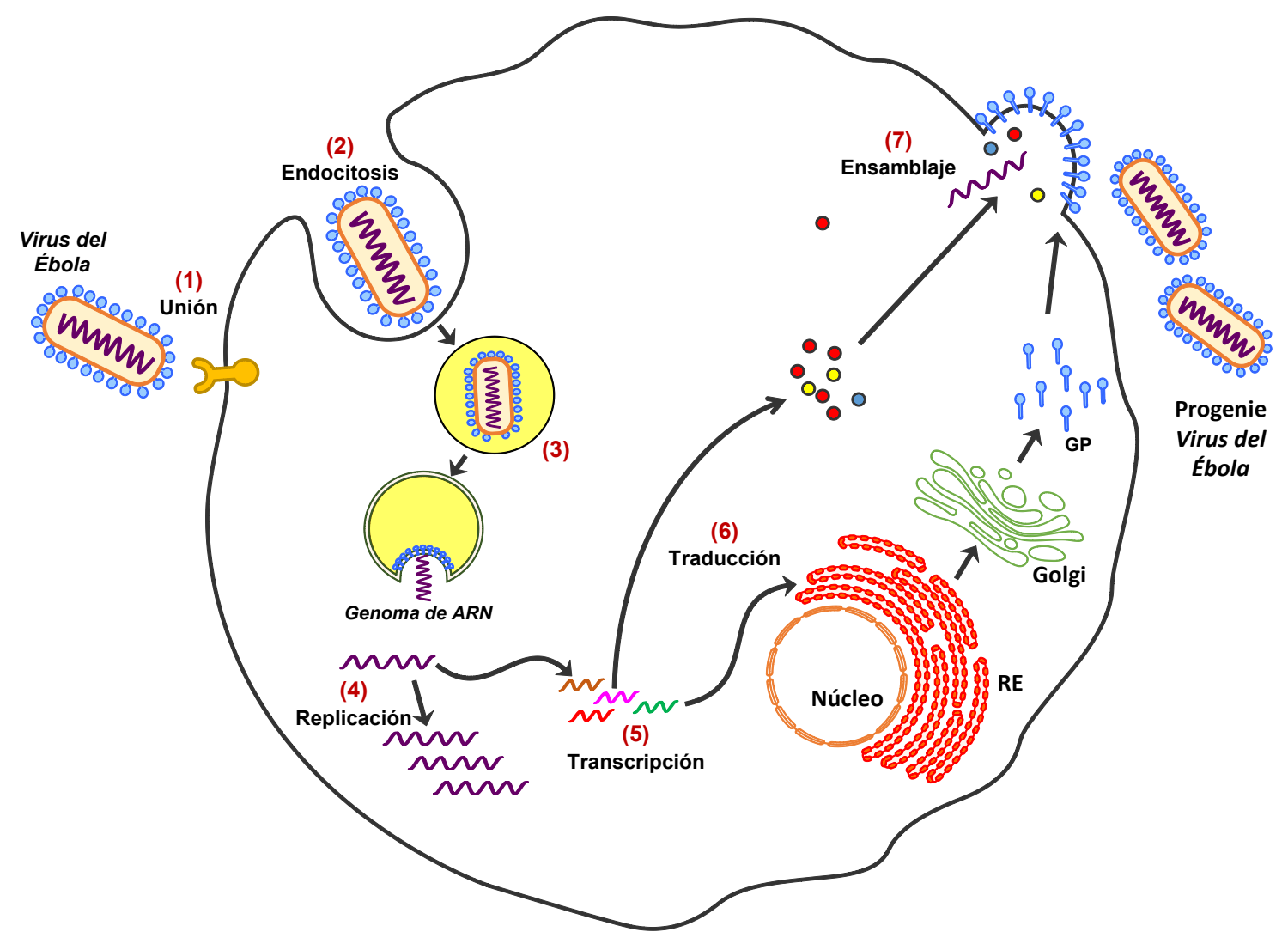

Figura 1. Ciclo de replicación del virus del Ébola en las células infectadas y sitios de acción de compuestos antivirales. (1) El virus del Ébola se une a receptores en la superficie celular (TIM-1) a través de la glicoproteína (GP). (2) El virus se internaliza formando un endosoma. 3. Mientras el virus termina su proceso de endocitosis, la GP es escindida por proteasas (CatL / B). Lo anterior favorece la fusión de la membrana del endosoma a las proteínas GP, la nucleocápside viral se libera en el citoplasma con la consecuente liberación del genoma del virus. (4) Replicación del genoma. (5) El genoma viral se transcribe con la ayuda de las proteínas virales VP35, VP30 y L. (6) Los ARNm virales se traducen. Los ARNm que codifican GP son llevados al retículo endoplasmático (RE) para ser sintetizadas y se modifican adicionalmente en el aparato de Golgi. (7) Genoma viral y proteínas estructurales y no estructurales son ensamblados para generar una nueva progenie viral. 
Los murciélagos frugívoros de la familia Pteropodidae son considerados el reservorio natural del virus (2), se cree que estos contagian a animales salvajes como chimpancés, macacos, gorilas, roedores, puercos espines y pequeños antílopes, los cuales pasan la enfermedad a los humanos cuando son cazados o encontrados muertos para su alimentación. De humano a humano se puede trasmitir el virus por contacto directo con secreciones corporales como saliva, sudor, vómitos, orina, heces y sangre, así como también por la manipulación de cuerpos de personas fallecidas (4). El virus se puede reproducir al unirse con la membrana de la célula animal en un proceso que es mediado por glicoproteínas de la envoltura viral, a través de fusión, endocitosis y translocación en células del sistema inmunitario, del sistema endotelial, del hígado, del riñón y fibroblastos. De igual forma también infecta macrófagos, monocitos y células dendríticas. Una vez ingresan a la célula blanco, el material genético del virus se libera y utiliza la maquinaria de la célula para su replicación, luego se da el ensamblaje y liberación de copias del virus que finalmente infectarán nuevas células (5).

Los pacientes pueden presentar manifestaciones clínicas entre el día 2 y 21 después de haber estado expuesto al virus, iniciando con fiebre, mialgia, escalofrío, astenia, dolor de cabeza, vómito y diarrea, posteriormente puede progresar rápidamente a erupciones cutáneas, complicaciones hemorrágicas, disfunción renal y hepática e insuficiencia del sistema cardiovascular que conllevan a shock y edema $(4,5)$. Los resultados de laboratorio muestran pancitopenia moderada en la cual la leucopenia cursa con neutrofilia y linfopenia, transaminasas elevadas con predominio de la transaminasa Glutámico-oxalacética (GOT) sobre la transaminasa Glutámico-pirúvica (GPT), elevación de la concentración sérica de creatinina, prolongación tanto del tiempo de protrombina como de tromboplastina y detección de productos de degradación de la fibrina (dímero-D), lo cual indica coagulación intravascular diseminada (6).
Diagnosticar la EVE no es fácil, debido principalmente a la inespecificidad de los síntomas iniciales que pueden confundirse con un simple resfriado, o confundir los síntomas avanzados con otras fiebres hemorrágicas víricas, por lo cual es necesario realizar un diagnóstico diferencial; sin embargo, se pueden confirmar los casos sospechosos por la detección de ARN, a través de la reacción en cadena de la polimerasa con transcriptasa inversa (RT-PCR), por la detección de antígenos virales a través de la técnica ELISA, por prueba de seroneutralización o por aislamiento del virus mediante cultivo celular (4). La determinación de IgM e IgG en sangre es útil para la monitorización de la respuesta inmune del paciente en la etapa tardía de la enfermedad (4). Si un paciente logra contrarrestar el virus, de tal forma que desaparezcan los síntomas y no presente ningún signo de infección, podrá ser considerado sano y dado de alta, siempre y cuando no se detecte el virus por RT-PCR en dos determinaciones cada 48 horas (4).

En la actualidad se conocen cinco especies del género ebola virus: Zaire ebolavirus, Sudan ebolavirus, Reston ebolavirus, Taï Forest ebolavirus y Bundibugyo ebolavirus, de los cuales Reston ebolavirus es originario de Asia y no de África y es el único que hasta el momento no es patógeno en humanos $(2,5)$. La EVE se presentó por primera vez por dos brotes simultáneos en 1976, uno por Sudan ebolavirus que afectó principalmente las ciudades de Nzara y el otro por Zaire ebolavirus que afectó a la ciudad de Yanbukú cerca del río Ébola, por el cual recibe su nombre (4).

Desde entonces, hasta la fecha se han presentado esporádicos brotes con tasas de letalidad que varían desde $40 \%$ hasta alcanzar un $90 \%$, mostrando cierta preferencia geográfica de acuerdo con los datos reportados. Así, Zaire ebolavirus afecta a África central y África occidental, Sudan ebolavirus afecta a África oriental, Taï Forest ebolavirus afecta a África occidental y Bundibugyo ebolavirus afecta tanto a África central como a África oriental (Tabla 1). 
Tabla 1. Cronología de los brotes por virus del Ébola.

\begin{tabular}{|c|c|c|c|c|c|}
\hline Año & Sitio & Cepa & $\begin{array}{c}\text { Tasa de } \\
\text { Mortalidad } \\
(\%)\end{array}$ & causa & Nota \\
\hline \multirow[t]{4}{*}{1976} & Nzara & Sudan & 46 & $\begin{array}{l}\text { Evidencia de } \\
\text { murciélagos en el } \\
\text { sitio de trabajo }\end{array}$ & $\begin{array}{c}\text { Fue la ciudad donde ocurrió } \\
\text { la primera epidemia con este } \\
\text { virus, pero fue reconocida } \\
\text { después de la epidemia en } \\
\text { Yambuku, los primeros en } \\
\text { infectarse fueron trabajadores } \\
\text { de una fábrica de algodón }\end{array}$ \\
\hline & Maridi & Sudan & 54 & $\begin{array}{l}\text { Por dos pacientes } \\
\text { de Nzara } \\
\text { hospitalizados en } \\
\text { esta ciudad }\end{array}$ & - \\
\hline & Yambuku & Zaire & 88 & Misión hospitalaria & - \\
\hline & Porton Down & Sudan & 0 & - & 1 caso resuelto \\
\hline 1977 & Tandala & Zaire & 100 & - & 1 caso sin resolver \\
\hline 1979 & Nzara & Sudan & 65 & $\begin{array}{c}\text { Evidencia de } \\
\text { murciélagos en el } \\
\text { sitio de trabajo }\end{array}$ & $\begin{array}{l}\text { Los primeros en infectarse } \\
\text { fueron unos trabajadores de } \\
\text { una fábrica de algodón }\end{array}$ \\
\hline 1989 & Reston (USA) & Reston & 0 & - & $\begin{array}{c}4 \text { casos en humanos resueltos } \\
\text { y } 550 \text { casos en primates no } \\
\text { humanos }\end{array}$ \\
\hline 1992 & Sinna (Italia) & Reston & 0 & - & $\begin{array}{c}55 \text { casos en primates no } \\
\text { humanos }\end{array}$ \\
\hline 1994 & $\begin{array}{l}\text { Tai (Costa de } \\
\text { Marfil) }\end{array}$ & Taï Forest & 0 & $\begin{array}{c}\text { Autopsia de un } \\
\text { chimpancé salvaje } \\
\text { encontrado muerto } \\
\text { en un bosque }\end{array}$ & 1 caso resuelto \\
\hline 1995 & Liberia & Taï Forest & 0 & Desconocido & Refugiados de la guerra civil \\
\hline $\begin{array}{l}1994- \\
1995\end{array}$ & $\begin{array}{l}\text { AndockMekouka } \\
\text { (Gabón) }\end{array}$ & Zaire & 64 & $\begin{array}{l}\text { Evidencia de } \\
\text { murciélagos en el } \\
\text { sitio de trabajo }\end{array}$ & $\begin{array}{c}\text { Trabajadores de campos de } \\
\text { extracción de oro }\end{array}$ \\
\hline 1995 & Kikwit (Zaire) & Zaire & 79 & $\begin{array}{c}\text { Epidemia } \\
\text { nosocomial }\end{array}$ & - \\
\hline \multirow[b]{2}{*}{1996} & $\begin{array}{l}\text { Mayibout II } \\
\text { (Gabón) }\end{array}$ & Zaire & 57 & $\begin{array}{c}\text { Chimpancé } \\
\text { encontrado muerto } \\
\text { cerca del pueblo } \\
\end{array}$ & - \\
\hline & Alice, TX (USA) & Reston & 0 & $\begin{array}{l}\text { Monos exportados } \\
\text { por una } \\
\text { exportadora de } \\
\text { Filipinas }\end{array}$ & $\begin{array}{c}2 \text { casos en primates no } \\
\text { humanos }\end{array}$ \\
\hline $\begin{array}{l}1996- \\
1997\end{array}$ & Booué (Gabón) & Zaire & 75 & $\begin{array}{l}\text { Manipuladores } \\
\text { de cadáveres de } \\
\text { antílopes }\end{array}$ & $\begin{array}{l}\text { El primer caso se dio en un } \\
\text { cazador del bosque }\end{array}$ \\
\hline $\begin{array}{c}2000- \\
2001 \\
\end{array}$ & Uganda & Sudan & 40,7 & Desconocido & - \\
\hline $\begin{array}{l}2001- \\
2002\end{array}$ & $\begin{array}{c}\text { Mendemba, } \\
\text { Mekambo, } \\
\text { Ilahounene, } \\
\text { NtoloOlloba y } \\
\text { Ekata }\end{array}$ & Zaire & $79-89$ & $\begin{array}{l}\text { Manipuladores } \\
\text { de cadáveres de } \\
\text { antílopes }\end{array}$ & - \\
\hline
\end{tabular}




\begin{tabular}{|c|c|c|c|c|c|}
\hline Año & Sitio & Сера & $\begin{array}{c}\text { Tasa de } \\
\text { Mortalidad } \\
(\%)\end{array}$ & causa & Nota \\
\hline $\begin{array}{l}2002- \\
2003\end{array}$ & Mbomo & Zaire & 90 & $\begin{array}{l}\text { Manipuladores } \\
\text { de cadáveres de } \\
\text { antílopes }\end{array}$ & - \\
\hline 2004 & Sudán & Sudan & 41 & Desconocida & - \\
\hline 2005 & Congo & Zaire & 83 & Desconocida & - \\
\hline $\begin{array}{l}2007- \\
2008\end{array}$ & Uganda & Bundibugyo & 42 & - & - \\
\hline $\begin{array}{l}2008- \\
2009\end{array}$ & Filipinas & Reston & 0 & - & $\begin{array}{c}6 \text { casos resueltos en humanos, } \\
\text { se han reportado infecciones en } \\
\text { cerdos }\end{array}$ \\
\hline 2011 & Uganda & Sudan & 100 & - & Un caso no resuelto \\
\hline 2012 & Uganda & Sudan & $57-71$ & - & - \\
\hline 2012 & $\begin{array}{c}\text { Rep. Democrática } \\
\text { de Congo }\end{array}$ & Bundibugyo & 51 & - & - \\
\hline 2014 & $\begin{array}{l}\text { Guinea, Sierra } \\
\text { Leona y Liberia }\end{array}$ & Zaire & $65-72$ & $\begin{array}{l}\text { Niño contagiado } \\
\text { por murciélago } \\
\text { frugívoro }\end{array}$ & $\begin{array}{c}\text { La OMS en agosto de } 2014 \\
\text { declaró oficialmente situación } \\
\text { de emergencia internacional de } \\
\text { salud pública }\end{array}$ \\
\hline
\end{tabular}

Actualmente no hay un tratamiento o vacuna específica disponible para el uso clínico y así combatir la mortal enfermedad, solo se tratan los síntomas con soluciones que contengan electrólitos, analgésicos, antieméticos, ansiolíticos, antidiarreicos y antibióticos, en casos graves de hemorragias severas se realizan transfusiones sanguíneas o componentes sanguíneos de acuerdo con cual sea el caso. También se practican estrategias de prevención con el fin de minimizar el riesgo de infección y controlar la enfermedad $(4,7)$.

Algunos fármacos no antivirales ya existentes, con perfiles de seguridad y farmacocinéticas bien establecidos en pacientes, han demostrado actividad in vitro e in vivo en modelos animales contra virus del Ébola, al impedir la entrada del virus a la célula huésped, actuando sobre la proteína de membrana de paso sencillo Niemann-Pick C1 (NPC1)(8); por tal razón han sido aprobadas por la Administración de Alimentos y Drogas (FDA) como agentes antivirales contra el virus del Ébola. Tal es el caso de la cloroquina, amiodarona, dronedarona, verapamilo, clomifeno, toremifeno y estatina (9).
Desde que sucedió el primer brote por virus del Ébola se ha venido investigando y desarrollando fármacos y vacunas experimentales como estrategias de control primario con resultados alentadores por la eficiente actividad contra virus del Ébola en roedores y en NHP, pero desconociendo aún su eficiencia en humanos (10).

Con base en lo anterior, se realizó una revisión bibliográfica de artículos publicados en inglés y en español, sin distinción en el tiempo, resultando 158 referencias científicas y seleccionando 108 de éstas, que fueron las de mejor enfoque en el tema de interés. Se consultaron sitios web como el de la Organización Mundial de la Salud (OMS), el Instituto Nacional de Alergias y Enfermedades Infecciosas, el Centro para el Control y la Prevención de Enfermedades; de igual forma se consultaron descriptores en ciencias de la salud y bases de datos como Pubmed, ScienceDirect, entre otros. Se emplearon las palabras claves: virus del Ébola, enfermedad por virus del Ébola; tratamiento, las cuales fueron los principales criterios de búsqueda, con el fin de establecer los avances científicos que se han logrado en cuanto a las estrategias terapéuticas contra la EVE. 


\section{Métodos de prevención}

A pesar de los temores y estigmas que se tienen en el mundo con la enfermedad causada por el virus del Ébola, es posible su prevención a través de capacitaciones educativas a la comunidad; la concientización de tener una buena higiene (limpieza y desinfección regular con detergentes en granjas de cerdos y monos y en el hogar de personas infectadas, así como también la higiene básica de las manos); las prácticas seguras de actividades como la caza de animales y la atención a enfermos; abandonar costumbres tradicionales consideradas como de alto riesgo de trasmisión del virus tales como son el consumo de carnes crudas y los ritos funerarios. Los profesionales de la salud y trabajadores de los laboratorios también pueden tener control de la infección haciendo buen uso de los equipos y materiales de protección personal, realizando prácticas seguras del manejo de muestras, inyectología e inhumación (4).

\section{Estrategias terapéuticas}

En un principio se realizaron experimentos con vacunas que contenían el virus del Ébola inactivo con adyuvantes Ribi o liposomas, con el fin de hacer más efectiva la respuesta inmune, sin embargo resultó exitoso solo en roedores, pero no lo fue en NHP, ya que no se observó en ellos protección contra la enfermedad (11). Por tal motivo fue necesario reformular el enfoque de las vacunas, avanzando en técnicas que permitieran efectividad en la actividad inmunológica (mediada por células T y B) contra el virus, como las vacunas basadas en ADN, partículas similares al virus (VPLs) y vacunas basadas en virus vectores que codificaran la glucoproteína (GP) del virus (12). Aun cuando el desarrollo de la actividad de estas vacunas se han probado, con resultados alentadores en modelos in vitro e in vivo (NHP y roedores) y en farmacología humana (ensayo clínico fase I) autorizado por la OMS, no hay en la actualidad ninguna vacuna disponible para el uso clínico (13). Sin embargo, se siguen realizando investigaciones fundamentales de una gran variedad de agentes quimioterapéuticos (Tabla 2) que prometen buenas expectativas de prevención y protección contra el virus del Ébola (14).

\section{Terapias antivirales}

\section{Proteína $C$ activada recombinante humana (rhAPC)}

La rhAPC actúa como un anticoagulante ya que inactiva los factores de la coagulación Va y VIIIa, impidiendo la formación de la trombina, la inducción de la quimiotaxis en neutrófilos y macrófagos y la generación de citoquinas, por lo tanto, puede considerarse a la rhAPC un agente anti-inflamatorio y profibrinolítico (15). Esta proteína fue fabricada por la empresa Eli Lilly como XIGRIS [Drotrecogina alfa (activada)], para tratar alteraciones de la coagulación inducidas por sepsis con alto riesgo de muerte en humanos, desde noviembre del año 2001 hasta octubre del 2011. La FDA notificó el retiro voluntario de este fármaco después de haberse demostrado por el ensayo PROWESS-SHOCK que no aportaba ningún beneficio a la supervivencia en pacientes con sepsis grave (16).

Sin embargo, estudios realizados en monos macacos Rhesus infectados con Zaire ebolavirus, han demostrado que la administración intravenosa con rhAPC 30 y 60 minutos después de la exposición durante 7 días, aumenta su supervivencia con disminución de la carga viral y reducción tanto de la activación de la coagulación como de la respuesta inflamatoria sistémica, por lo cual sugiere que el tratamiento con rhAPC puede ser considerado como una buena alternativa para mejorar la supervivencia en los pacientes con EVE (17). 
Avances científicos en las estrategias terapéuticas contra la enfermedad por virus del ébola

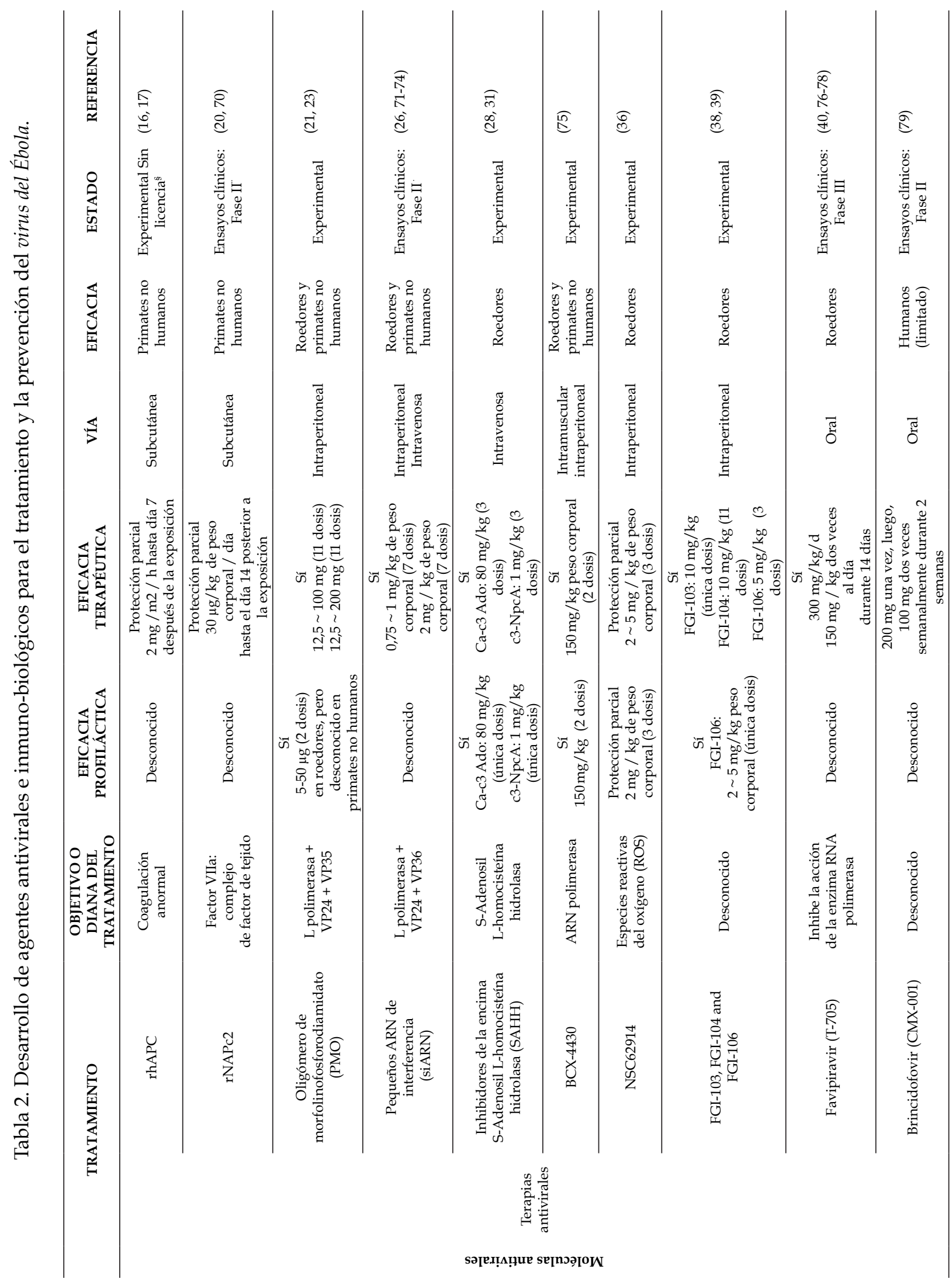




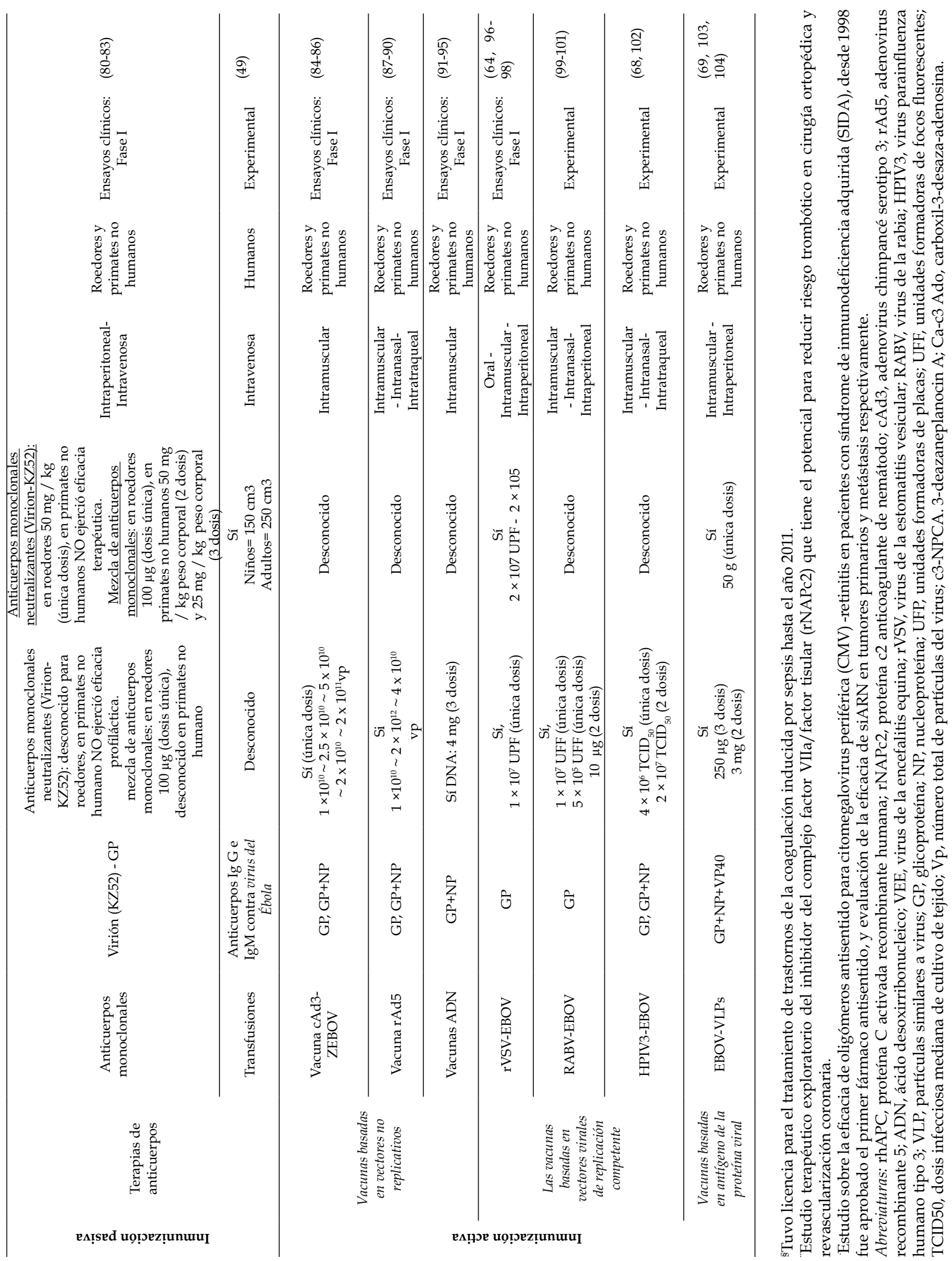


Proteína C2 anticoagulante recombinante de nematodos (rNAPc2)

La rNAPc2 es una proteína de 85 aminoácidos aislada del anquilostoma, Ancylostoma caninum, la cual actúa como un potente inhibidor del factor tisular (complejo FT-VIIa), bloqueando la formación del coágulo desde el primer paso de la vía extrínseca en la cascada de coagulación, ya que inicialmente se une a zimógenos (factor $X$ o factor $X a$ ) en un sitio diferente al sitio catalítico, resultando así dos complejos bimoleculares: rNAPc2 + factor $\mathrm{X}$ o Xa y el factor VIIa + factor tisular, ambos complejos se unen formando el gran complejo cuaternario (FVIIa/TF-Xa/rNAPc2)(18, 19). Actualmente se está investigando la utilidad de esta proteína en la inhibición de la coagulación intravascular diseminada en síndrome coronario agudo y en enfermedades causadas por filovirus $(19,20)$.

$\mathrm{Su}$ administración en monos macaco Rhesus después de 10 minutos y 24 horas durante 14 días post-exposición con dosis letal del virus del Ébola, ha demostrado que ayuda a disminuir la respuesta pro-inflamatoria con disminución sérica de la interleuquina 6 y proteínas quimiostáticas de monocitos 1 (MCP1), lo cual le permite ser considerado una posible alternativa en el tratamiento contra este mortal virus (20).

\section{Oligonucleótidos antisentido:}

(oligómero de morfolinofosforodiamidatoPMOs) y ARN de interferencia (siRNA)

Los PMOs son moléculas pequeñas monocatenarias de secuencias de ácidos nucleicos, complementaria con la secuencia de cierto ARNm, las cuales al unirse producen su inactivación, es decir, la cadena individual de ARNm que se une a la cadena antisentido no puede ser traducida y por consecuente se genera un bloqueo de la producción de la proteína (21).

Estas moléculas se están estudiando actualmente para contrarrestar la EVE, ellas son PMOs AVI7537, AVI-7539 y AVI-6002. PMOs AVI-7537 está dirigida a los genes que codifican la proteína VP24 viral, AVI-7539 está dirigida a los genes que codifican la proteína VP35 viral y AVI-6002 es una combinación de las dos anteriores. Estudios realizados por Warren et al. (2015), revelan que aunque AVI-7537 y AVI-6002 disminuyeron la replicación viral con valores similares en roedores y NHP, se considera a AVI-7537 como el único exitoso contra esta enfermedad letal, ya que PMOs AVI-7539 por sí solo no genera protección contra virus del Ébola, detectándose hasta $10^{6}$ copias del genoma viral / $\mathrm{mL}$ de suero el noveno día post-exposición de 14 días de experimentación total (22); por su parte Swenson et al. (2009), observaron que la conjugación de PMOs con péptidos ricos en arginina mejoraron la calidad antiviral in vivo en ratones contra dosis letal del virus, hasta alcanzar 93\% de tasa de supervivencia (23).

Por otra parte, los ARN que utilizan la máquina de interferencia de ARN para bloquear la síntesis de proteínas virales (nanopartículas de lípidos-siRNA: TKM-Ébola), son también oligonucleótidos, pero de doble cadena, con una secuencia específica que transfecta la célula y se empareja con el ARNm que expresa la proteína diana, tales como son la polimerasa L, proteína VP24 y VP35 (24). TKM-Ébola es un siARN (25) considerado un potencial terapéutico postexposición con una dosis letal de virus del Ébola en NHP, fue probado con dosis intravenosa de $2 \mathrm{mg} / \mathrm{kg}$ en grupos de macacos Rhesus, demostrando hasta $100 \%$ de protección (26). Este fármaco ha sido aprobado para ensayos clínicos de fase II por la FDA (25).

Inhibidores de la encima S-Adenosil L-homocisteína hidrolasa (SAHH): La encima $\mathrm{SAHH}$ cataliza la hidrólisis reversible de S-Adenosil L-homocisteína(SAH) a Lhomocisteína y adenosina, las cuales son útiles en la transferencia de grupos metilos en el metabolismo celular por la acción de S-Adenosilmetionina (SAM) y en la transferencia de energía en forma de ATP Y ADP, respectivamente (27). Se cree que al inhibir 
la acción de esta enzima se ejercerá actividad antiviral al inhibir con ello la metilación del polinucleótido 5' cap del ARNm viral (no se adiciona al extremo $5^{\prime}$ del ARNm el nucleótido 7-metil guanosina, necesario para la replicación del virus) (28); por lo tanto, se han estudiado dos análogos de adenosina, carboxil-3-desazaadenosina (Ca-c3 Ado) y 3-Deazaneplanocin A (c3-NpcA), los cuales actúan como inhibidores competitivos de la enzima SAHH y se ha comprobado su actividad antiviral contra una gran variedad de virus de material genético tanto $\operatorname{ARN}$ como $\operatorname{ADN}(29,30)$.

En roedores se ha observado que solo una dosis de $80 \mathrm{mg} / \mathrm{kg}$ peso corporal de Ca-c3 Ado o una dosis de $1 \mathrm{mg} / \mathrm{kg}$ peso corporal dec3-NpcA, ejerce protección contra dosis letal del virus del Ébola $(28,31)$.

\section{Nucleósidos análogo BCX4430}

El BCX4430 es un análogo de adenosina sintético desarrollado por BioCryst farmacéuticos, que inhibe la función de la ARN polimerasa viral y ofrece protección contra la infección con virus del Ébola en modelos animales (32).

Por reportes positivos de un medicamento contra virus Ébola, realizados en septiembre del 2014 por el Doctor Gorbee Logan en Liberia, se estudió el análogo de citosina llamado Lamivudina, el cual es utilizado como antirretroviral para el tratamiento de VIH y hepatitis B, ya que inhibe la transcripción inversa de estos virus; sin embargo, se demostró que Lamivudina es un inhibidor débil de ADN polimerasa alfa, beta y gama en mamíferos, por tal razón se podría decir que Lamivudina no podría inhibir la replicación de un virus de ARN de cadena negativa $(33,34)$.

\section{Molécula NSC62914}

La NSC62914 es un compuesto antioxidante que actúa eliminando las especies reactivas del oxígeno (ROS), la acumulación excesiva de ROS puede causar daño celular y contribuir al desarrollo de la patogénesis de varios virus (35). Este compuesto proporciona efecto profiláctico y en menor medida efecto terapéutico en roedores infectados con dosis letal de virus del Ébola (36).

\section{Compuestos con actividad antiviral FGI-103, FGI-104, FGI-106, LJ-001}

Estos compuestos han demostrado 80 a $100 \%$ de protección profiláctica y terapéutica en roedores (37-39); aunque no se conocen completamente los mecanismos de actividad antiviral de FGI103 y FGI-104, se cree que FGI-106 actúa sobre la replicación viral (39) y LJ-001 se une a la envoltura del virus, impidiendo la unión viruscélula del virus del Ébola (12).

\section{Pyrazinecarboximide derivado T-705 (favipiravir)}

Inicialmente fue publicado como un inhibidor de la replicación del virus de la gripe, sin embargo se ha demostrado su potente actividad contra segmentos de virus ARN de cadena negativa, entre estos el virus del Ébola, observándose disminución de la carga viral en roedores dos días pos-tratamiento con tan solo $300 \mathrm{mg} /$ $\mathrm{Kg}$ diarios, iniciando tratamiento 6 días posinfección (40).

Sin embargo, fue necesario el uso de favipiravir en humanos durante la epidemia del 2014 en África Occidental, autorizada por el ministerio de salud de Japón (41), administrándose en niños dosis que variaron, de acuerdo con su peso, desde $500 \mathrm{mg}$ hasta $2000 \mathrm{mg}$, y en adultos se administró una dosis fija de $2500 \mathrm{mg}$ durante 10 días (42).

\section{Brincidofovir (CMX-001)}

El Brincidofovir es un análogo de nucleótido de amplio espectro contra varios virus de ADN (incluyendo virus vaccinia, ortopoxvirus, citomegalovirus y adenovirus), está conformado por un conjugado lipídico de cidofovir que se 
convierte intracelularmente en difosfato de cidofovir (antiviral activo) (43).

Este fármaco de disponibilidad oral ha demostrado ser eficaz por pruebas in vitro contra virus ARN (virus del Ébola) (44); por tal motivo la FDA aprobó su uso en caso de emergencia el 6 de octubre del 2014 (45), y fue administrado en varios pacientes con la enfermedad con resultados alentadores, requiriendo mayores estudios con respecto a su eficacia y seguridad, ya que a estos pacientes también se le administraron otros medicamentos (46).

\section{Carbazatooxo-tetrahidroquinolina}

Es una pequeña molécula anti-viral, que se ha probado in vitro para bloquear la entrada del virus Ébola por la inhibición de proteasas de la célula huésped (catepsinaLy B), las cuales ayudan a la escisión de una glucoproteína viral de superficie (GP), lo cual es requerido por el virus para fusionarse con la membrana de la célula huésped $(47,48)$.

\section{Inmunización pasiva: terapias de anticuerpos Terapias transfusionales}

Teniendo en cuenta que ningún tratamiento está desarrollado para esta enfermedad, se realizaron inmunizaciones pasivas con transfusiones de plasma rico en anticuerpos IgG de pacientes que se han recuperado de la enfermedad, obteniendo resultados alentadores (49)

Luego de la reunión de un panel de expertos, dirigida por la OMS el 4 y 5 de septiembre de 2014, se aumentó el interés por tratamientos experimentales de inmunización pasiva, ya que al término de la reunión dieron prioridad a las investigaciones sobre el tratamiento con sangre o plasma de convalecientes (50).

\section{Anticuerpos monoclonales (mAbs)}

MB-300 es una mezcla de tres anticuerpos monoclonales humanizados de ratón c13C6,
h-13F6 y c6D8. La administración de MB-300 tras la exposición del virus del Ébola en monos macacos Rhesus demostró una inmunoprotección significativa (51).

Otros tres anticuerpos monoclonales murinos: m1H3, m2G4 y m4G7,denominado ZMAb, fueron humanizados para dar origen a anticuerpos monoclonales c1H3, c2G4 y c4G7 denominado cZMAb, el cual demostró proteger sostenidamente en NHP contra re-exposiciones con dosis letal de virus del Ébola (52). La unión de estos anticuerpos monoclonales humanizados, que son producidos transgénicamente y cultivados en plantas de tabaco de la especie Nicotina benthamiana (MB-300-cZMAb), dieron lugar al medicamento denominado ZMapp, suero inmunológico que busca estimular el sistema inmune del paciente para que responda de forma más rápida y eficaz al virus, el cual está dirigido contra la glucoproteína $(\mathrm{Gp})$ del virus del Ébola. ZMapp fue capaz de proteger a monos macacos Rhesus después de 3 y 5 días tras exposición con dosis letal de virus del Ébola, demostrando una respuesta inmune humoral y mediada por células específicas de glucoproteína viral $(53,54)$.

El Instituto Nacional de Alergias y Enfermedades Infecciosas (NIAID) patrocinará la realización del ensayo clínico fase I de ZMapp, cuyo identificador ClinicalTrials.gov es NCT02363322 (55).

Por otra parte, Lee et al. (2008) presentaron una estructura que puede ser incentivo de futuras inmunoterapias, la cual consiste en la unión de la glucoproteína viral con un anticuerpo neutralizante (KZ52), el cual es un derivado de un superviviente humano del brote presentado en 1995 en Kikwit (56).

\section{Inmunización activa}

La creación de una vacuna contra virus del Ébola está encaminada en un preparado que contenga genes que codifiquen la glucoproteína del virus, 
cuyo objetivo sería provocar una respuesta inmune mediada por células $\mathrm{T}$ y $\mathrm{B}$.

\section{Vacuna rAd5}

La rAd5 es una vacuna experimental que utiliza un adenovirus recombinante serotipo 5, la cual expresa la glucoproteína (GP) del virus del Ébola. Se ha demostrado que una dosis intramuscular puede ejercer protección contra el virus del Ébola en modelos animales, mediados por la inmunidad celular de las moléculas CD8 que expresan las células T (57).

\section{Vacuna cAd3-ZEBOV}

La vacuna cAd3-ZEBOV utiliza como vector un adenovirus Ad3 derivado de chimpancés, el vector transporta segmentos del material genético que codifica la glucoproteína (GP) de una o dos especies del virus del Ébola: Zaire ebolavirus y Sudan ebolavirus (58). De acuerdo con lo anterior, se están experimentando dos formas, la monovalente (ClinicalTrials.gov número, NCT02240875) y la bivalente (ClinicalTrials. gov número, NCT02231866) por la compañía farmacéutica GlaxoSmithKline (GSK) y el Instituto Nacional de Alergias y Enfermedades Infecciosas de los EE.UU. (NIAID) $(59,60)$.

\section{Vacuna rVSV-ZEBOV}

La vacuna rVSV-ZEBOV utiliza el virus atenuado de la estomatitis vesicular, en el cual se ha insertado el gen que codifica la glucoproteína (GP) del virus del Ébola. La vacuna ha sido probada por vía intraperitoneal con una dosis de $2 \times 10^{5}$ unidades formadoras de placa (PFU) en ratones, mostrando $100 \%$ de protección contra dosis letal del virus (61). También fue administrada en otro roedor como el hámster, con el objetivo de ensayar su eficacia contra dos virus: virus del Ébola y virus Andes, aplicándose por vía intraperitoneal en una dosis de $10^{5} \mathrm{PFU}$ 28 días pre-exposición, lográndose una completa protección contra ambos virus (62). Fue probada también por vía intramuscular en macacos
Rhesus y macacos cynomolgus con una dosis de $2 \times 10^{7}$ PFU, mostrando protección total contra el virus del Ébola, tanto 20-30 minutos como 28-36 días post-exposición (63-65).

El estudio de seguridad y eficacia de las vacunas experimentales cAd3-EBOZ y VSV-ZEBOV iniciado el 2 de febrero de 2015 en Monrovia, Liberia, por el Ministerio de Salud de Liberia y el Instituto Nacional de Alergias y Enfermedades Infecciosas (NIAID) de los Institutos Nacionales de Salud, informaron el 7 de mayo de ese año las exitosas inscripciones de 1.500 personas voluntarias para dar inicio al ensayo clínico fase II (66). De igual forma, se puso en marcha en abril del 2015 el ensayo clínico diseñado para evaluar la eficacia y seguridad contra virus del Ébola de la vacuna VSV-ZEBOV en Sierra Leona (67).

Otras vacunas candidatas que se han investigado con resultados esperanzadores son:

Vacuna HPIV3, la cual utiliza como vector el virus para influenza humano tipo 3 expresando la glicoproteína viral (GP), que con una o dos dosis es capaz de proteger a NHP contra dosis letal de virus del Ébola (68).

Vacunas con partículas similares al virus VLPs, las cuales son partículas proteicas que carecen de material genético viral y se derivan de una o más proteínas estructurales del virus (69).

\section{CONCLUSIÓN}

Desde que se descubrió el virus del Ébola en el continente africano, todavía no existen fármacos antivirales o vacunas con licencia para combatirlo. El avance ha sido lento, pero hay un gran equipo de líderes mundiales que trabajan arduamente con el objetivo único de reducir la tasa de letalidad y conseguir inmunización completa en la población con campañas de vacunación masivas, tal como lo acordaron los participantes de una reunión consultiva dirigida por la OMS. 
En la actualidad ha habido un gran número de intentos en prácticas clínicas y estrategias terapéuticas probadas in vitro e in vivo en modelos animales con resultados alentadores, las cuales incluyen anticuerpos monoclonales, medicamentos basados en ARN, transfusiones de plasma de pacientes convalecientes, moléculas antivirales, vacunas, entre otros; tratando de encontrar la formas de acelerar la evaluación y el uso de estos compuestos para lograr erradicar por completo los brotes por virus del Ébola.

Desde que la EVE fue declarada una "emergencia de salud pública de importancia internacional", se han sumado esfuerzos en equipo de comunidades locales, comunidades internacionales y funcionarios de la salud, encaminado en la orientación, concientización e importancia de los mecanismos de prevención de la propagación, la vigilancia y cuidado de la EVE, los cuales son factores fundamentales para lograr los objetivos estratégicos que aspira alcanzar la OMS en los próximos años.

\section{CONFLICTO DE INTERESES}

Los autores manifiestan que no tienen conflicto de intereses con respecto a esta investigación.

\section{FINANCIACIÓN}

Vicerrectoría de Investigaciones de la Universidad de Cartagena, plan de fortalecimiento y sostenibilidad del Grupo Bioquímica y Enfermedad.

\section{BIBLIOGRAFÍA}

1. Mahanty S, Bray M. Pathogenesis of filoviral haemorrhagic fevers. Lancet Infect Dis. 2004 Aug; 4(8):487-98.

2. Ramanan $P$, Shabman RS, Brown CS, Amarasinghe GK, Basler CF, Leung DW. Filoviral immune evasion mechanisms. Viruses. 2011 Sep; 3(9):1634-49.

3. Mohan GS, Li W, Ye L, Compans RW, Yang C. Antigenic subversion: a novel mechanism of host immune evasion by Ebola virus. PLoS Pathog. 2012; 8(12):e1003065.

4. Formenty P. Chapter 9 - Ebola Virus Disease. Emerging Infectious Diseases. 2014:121-34.

5. Miller K, College K. Infection Mechanism of Genus Ebolavirus. 2010 [updated 201026 Octubre 2014; cited 201510 Abril]; Available from: https://microbewiki.kenyon.edu/index.php/Infection_ Mechanism_of_Genus_Ebolavirus.

6. Kortepeter MG, Bausch DG, Bray M. Basic clinical and laboratory features of filoviral hemorrhagic fever. J Infect Dis. 2011 Nov; 204 Suppl 3:S810-6.

7. Kendall RE, Gosser RA, Schulz LT, Trapskin PJ. Anti-diarrheal medication use in the treatment of Ebola virus-induced diarrhea. Travel Medicine and Infectious Disease. 2015; 13(2): 205-6.

8. White JM, Schornberg KL. A new player in the puzzle of filovirus entry. Nat Rev Microbiol. 2012 May; 10(5):317-22.

9. Gehring G, Rohrmann K, Atenchong N, Mittler E, Becker S, Dahlmann F, et al. The clinically approved drugs amiodarone, dronedarone and verapamil inhibit filovirus cell entry. J Antimicrob Chemother. 2014 Aug; 69(8):2123-31.

10. Nina J. Ebolavirosis: a 2014 review for clinicians. Acta Med Port. 2014 Sep-Oct; 27(5):625-33.

11. Geisbert TW, Pushko P, Anderson K, Smith J, Davis KJ, Jahrling PB. Evaluation in nonhuman primates of vaccines against Ebola virus. Emerg Infect Dis. 2002 May; 8(5):503-7. 
12. de Wit E, Feldmann $H$, Munster VJ. Tackling Ebola: new insights into prophylactic and therapeutic intervention strategies. Genome Med. 2011; 3(1):5.

13. WHO. Experimental Ebola vaccines. 2014 [updated 201401 Octubre 2014; cited 201520 de Marzo]; Available from: http://www.who.int/mediacentre/news/ebola/01-october-2014/en/.

14. Li H, Ying T, Yu F, Lu L, Jiang S. Development of therapeutics for treatment of Ebola virus infection. Microbes Infect. 2015 Feb; 17(2):109-17.

15. Yen JY, Garamszegi S, Geisbert JB, Rubins KH, Geisbert TW, Honko A, et al. Therapeutics of Ebola hemorrhagic fever: whole-genome transcriptional analysis of successful disease mitigation. J Infect Dis. 2011 Nov; 204 Suppl 3:S1043-52.

16. (FDA) FaDA. FDA Drug Safety Communication: Voluntary market withdrawal of Xigris [drotrecogin alfa (activated)] due to failure to show a survival benefit. 2011 [updated 2011 10/25/2011 cited 201526 March]; Available from: http://www.fda.gov/Drugs/DrugSafety/ucm277114.htm.

17. Hensley LE, Stevens EL, Yan SB, Geisbert JB, Macias WL, Larsen T, et al. Recombinant human activated protein $\mathrm{C}$ for the postexposure treatment of Ebola hemorrhagic fever. J Infect Dis. 2007 Nov 15;196 Suppl 2:S390-9.

18. Bergum PW, Cruikshank A, Maki SL, Kelly CR, Ruf W, Vlasuk GP. Role of zymogen and activated factor $X$ as scaffolds for the inhibition of the blood coagulation factor VIIa-tissue factor complex by recombinant nematode anticoagulant protein c2. J Biol Chem. 2001 Mar 30;276(13):10063-71.

19. Lee AY, Vlasuk GP. Recombinant nematode anticoagulant protein $\mathrm{c} 2$ and other inhibitors targeting blood coagulation factor VIIa/tissue factor. J Intern Med. 2003 Oct;254(4):313-21.

20. Geisbert TW, Hensley LE, Jahrling PB, Larsen T, Geisbert JB, Paragas J, et al. Treatment of Ebola virus infection with a recombinant inhibitor of factor VIIa/tissue factor: a study in rhesus monkeys. Lancet. 2003 Dec 13;362(9400):1953-8.

21. Warfield KL, Swenson DL, Olinger GG, Nichols DK, Pratt WD, Blouch R, et al. Gene-specific countermeasures against Ebola virus based on antisense phosphorodiamidate morpholino oligomers. PLoS Pathog. 2006 Jan;2(1):e1.

22. Warren TK, Whitehouse CA, Wells J, Welch L, Heald AE, Charleston JS, et al. A single phosphorodiamidate morpholino oligomer targeting VP24 protects rhesus monkeys against lethal Ebola virus infection. MBio. 2015;6(1).

23. Swenson DL, Warfield KL, Warren TK, Lovejoy C, Hassinger JN, Ruthel G, et al. Chemical modifications of antisense morpholino oligomers enhance their efficacy against Ebola virus infection. Antimicrob Agents Chemother. 2009 May;53(5):2089-99.

24. Kimberlin CR, Bornholdt ZA, Li S, Woods VL, Jr., MacRae IJ, Saphire EO. Ebolavirus VP35 uses a bimodal strategy to bind dsRNA for innate immune suppression. Proc Natl Acad Sci U S A. 2010 Jan 5;107(1):314-9.

25. McCarthy M. FDA allows second experimental drug to be tested in Ebola patients. BMJ. 2014;349:g5103.

26. Geisbert TW, Lee AC, Robbins M, Geisbert JB, Honko AN, Sood V, et al. Postexposure protection of non-human primates against a lethal Ebola virus challenge with RNA interference: a proof-of-concept study. Lancet. 2010 May 29;375(9729):1896-905.

27. Chiang PK, Gordon RK, Tal J, Zeng GC, Doctor BP, Pardhasaradhi K, et al. S-Adenosylmethionine and methylation. FASEB J. 1996 Mar;10(4):471-80.

28. Bray M, Driscoll J, Huggins JW. Treatment of lethal Ebola virus infection in mice with a single dose of an S-adenosyl-L-homocysteine hydrolase inhibitor. Antiviral Res. 2000 Feb;45(2):135-47.

29. Montgomery JA, Clayton SJ, Thomas HJ, Shannon WM, Arnett G, Bodner AJ, et al. Carbocyclic analogue of 3-deazaadenosine: a novel antiviral agent using S-adenosylhomocysteine hydrolase as a pharmacological target. J Med Chem. 1982 Jun;25(6):626-9. 
30. Glazer RI, Knode MC, Tseng CK, Haines DR, Márquez VE. 3-Deazaneplanocin A: a new inhibitor of S-adenosylhomocysteine synthesis and its effects in human colon carcinoma cells. Biochem Pharmacol. 1986 Dec 15;35(24):4523-7.

31. Bray M, Raymond JL, Geisbert T, Baker RO. 3-deazaneplanocin A induces massively increased interferon-alpha production in Ebola virus-infected mice. Antiviral Res. 2002 Jul;55(1):151-9.

32. Warren TK, Wells J, Panchal RG, Stuthman KS, Garza NL, van Tongeren SA, et al. Protection against filovirus diseases by a novel broad-spectrum nucleoside analogue BCX4430. Nature. 2014 Apr $17 ; 508(7496): 402-5$.

33. Hart GJ, Orr DC, Penn CR, Figueiredo HT, Gray NM, Boehme RE, et al. Effects of (-)-2'-deoxy-3'thiacytidine (3TC) $5^{\prime}$-triphosphate on human immunodeficiency virus reverse transcriptase and mammalian DNA polymerases alpha, beta, and gamma. Antimicrob Agents Chemother. 1992 Aug;36(8):1688-94.

34. Hensley LE, Dyall J, Olinger GG, Jr., Jahrling PB. Lack of effect of lamivudine on Ebola virus replication. Emerg Infect Dis. 2015 Mar;21(3):550-2.

35. Kim S, Kim MJ, Park DY, Chung HJ, Kim CH, Yoon JH, et al. Mitochondrial reactive oxygen species modulate innate immune response to influenza A virus in human nasal epithelium. Antiviral Res. 2015 Apr 28.

36. Panchal RG, Reid SP, Tran JP, Bergeron AA, Wells J, Kota KP, et al. Identification of an antioxidant small-molecule with broad-spectrum antiviral activity. Antiviral Res. 2012 Jan;93(1):23-9.

37. Kinch MS, Yunus AS, Lear $C$, Mao $H$, Chen $H$, Fesseha $Z$, et al. FGI-104: a broad-spectrum small molecule inhibitor of viral infection. Am J Transl Res. 2009;1(1):87-98.

38. Warren TK, Warfield KL, Wells J, Enterlein S, Smith M, Ruthel G, et al. Antiviral activity of a smallmolecule inhibitor of filovirus infection. Antimicrob Agents Chemother. 2010 May;54(5):2152-9.

39. Aman MJ, Kinch MS, Warfield K, Warren T, Yunus A, Enterlein S, et al. Development of a broadspectrum antiviral with activity against Ebola virus. Antiviral Res. 2009 Sep;83(3):245-51.

40. Oestereich L, Ludtke A, Wurr S, Rieger T, Munoz-Fontela C, Gunther S. Successful treatment of advanced Ebola virus infection with T-705 (favipiravir) in a small animal model. Antiviral Res. 2014 May; 105:17-21.

41. Nagata T, Lefor AK, Hasegawa M, Ishii M. Favipiravir: a new medication for the Ebola virus disease pandemic. Disaster Med Public Health Prep. 2014 Feb;9(1):79-81.

42. Bouazza N, Treluyer JM, Foissac F, Mentre F, Taburet AM, Guedj J, et al. Favipiravir for children with Ebola. Lancet. 2015 Feb 14;385(9968):603-4.

43. Florescu DF, Keck MA. Development of CMX001 (Brincidofovir) for the treatment of serious diseases or conditions caused by dsDNA viruses. Expert Rev Anti Infect Ther. 2014 Oct;12(10):1171-8.

44. Schepers JT. Chimerix's Brincidofovir Has in Vitro Activity Against Ebola. 2014 [updated 2014 03 Septiembre 2014; cited 201511 Mayo]; Available from: http://ir.chimerix.com/releasedetail. cfm?releaseid $=868807$.

45. Schepers JT. Chimerix Announces Emergency Investigational New Drug Applications for Brincidofovir Authorized by FDA for Patients With Ebola Virus Disease. 2014 [updated 201406 Octubre 2014; cited 201511 Mayo]; Available from: http://ir.chimerix.com/releasedetail.cfm?releaseid=874647.

46. Giahyue JH. Médicos comienzan ensayos de fármacos no probados contra el ébola en África Occidental. Thomson Reuters. 2015.

47. Shah PP, Wang T, Kaletsky RL, Myers MC, Purvis JE, Jing H, et al. A small-molecule oxocarbazate inhibitor of human cathepsin L blocks severe acute respiratory syndrome and ebola pseudotype virus infection into human embryonic kidney 293T cells. Mol Pharmacol. 2010 Aug;78(2):319-24.

48. Gnirss K, Kuhl A, Karsten C, Glowacka I, Bertram S, Kaup F, et al. Cathepsins B and L activate Ebola but not Marburg virus glycoproteins for efficient entry into cell lines and macrophages independent of TMPRSS2 expression. Virology. 2012 Mar 1; 424(1):3-10. 
49. Mupapa K, Massamba M, Kibadi K, Kuvula K, Bwaka A, Kipasa M, et al. Treatment of Ebola hemorrhagic fever with blood transfusions from convalescent patients. International Scientific and Technical Committee. J Infect Dis. 1999 Feb;179 Suppl 1:S18-23.

50. OMS. Tratamientos experimentales: aumenta el interés en el uso de sangre entera o plasma obtenidos de personas que se han recuperado de la enfermedad por el virus del Ébola (tratamientos con productos obtenidos de convalecientes). 2014 [updated 201426 Sep 2014; cited 201511 May]; Available from: http://www.who.int/mediacentre/news/ebola/26-september-2014/es/.

51. Olinger GG, Jr., Pettitt J, Kim D, Working C, Bohorov O, Bratcher B, et al. Delayed treatment of Ebola virus infection with plant-derived monoclonal antibodies provides protection in rhesus macaques. Proc Natl Acad Sci U S A. 2012 Oct 30;109(44):18030-5.

52. Audet J, Wong G, Wang H, Lu G, Gao GF, Kobinger G, et al. Molecular characterization of the monoclonal antibodies composing ZMAb: a protective cocktail against Ebola virus. Sci Rep. 2014;4:6881.

53. Qiu X, Wong G, Audet J, Bello A, Fernando L, Alimonti JB, et al. Reversion of advanced Ebola virus disease in nonhuman primates with ZMapp. Nature. 2014 Oct 2;514(7520):47-53.

54. Qiu X, Audet J, Wong G, Pillet S, Bello A, Cabral T, et al. Successful treatment of ebola virus-infected cynomolgus macaques with monoclonal antibodies. Sci Transl Med. 2012 Jun 13;4(138):138ra81.

55. ClinicalTrials.gov. Putative Investigational Therapeutics in the Treatment of Patients With Known Ebola Infection. 2015 [updated 201513 Feb 2015; cited 201511 May]; Available from: https://clinicaltrials. gov/ct2/show/NCT02363322?term=ebola\&rank $=11$.

56. Lee JE, Fusco ML, Hessell AJ, Oswald WB, Burton DR, Saphire EO. Structure of the Ebola virus glycoprotein bound to an antibody from a human survivor. Nature. 2008 Jul 10;454(7201):177-82.

57. Sullivan NJ, Hensley L, Asiedu C, Geisbert TW, Stanley D, Johnson J, et al. CD8+ cellular immunity mediates rAd5 vaccine protection against Ebola virus infection of nonhuman primates. Nat Med. 2008 Sep;17(9):1128-31.

58. Tully CM, Lambe T, Gilbert SC, Hill AV. Corrections. Emergency Ebola response: a new approach to the rapid design and development of vaccines against emerging diseases. Lancet Infect Dis. 2015 Mar;15(3):263.

59. ClinicalTrials.gov. A Study to Assess New Ebola Vaccines, cAd3-EBO Z and MVA-BN® Filo. 2014 [updated 201429 Jan 2015; cited 201508 Abr]; Available from: https://clinicaltrials.gov/ct2/show/ NCT02240875.

60. ClinicalTrials.gov. Safety, Tolerability, and Immunogenicity of the Ebola Chimpanzee Adenovirus Vector Vaccine (cAd3-EBO), VRC-EBOADC069-00-VP, in Healthy Adults. 2014 [updated 201409 Dec 2014; cited 201508 Abr]; Available from: https://clinicaltrials.gov/ct2/show/NCT02231866.

61. Feldmann H, Jones SM, Daddario-DiCaprio KM, Geisbert JB, Stroher U, Grolla A, et al. Effective postexposure treatment of Ebola infection. PLoS Pathog. 2007 Jan;3(1):e2.

62. Tsuda Y, Safronetz D, Brown K, LaCasse R, Marzi A, Ebihara H, et al. Protective efficacy of a bivalent recombinant vesicular stomatitis virus vaccine in the Syrian hamster model of lethal Ebola virus infection. J Infect Dis. 2011 Nov;204 Suppl 3:S1090-7.

63. Geisbert TW, Daddario-Dicaprio KM, Geisbert JB, Reed DS, Feldmann F, Grolla A, et al. Vesicular stomatitis virus-based vaccines protect nonhuman primates against aerosol challenge with Ebola and Marburg viruses. Vaccine. 2008 Dec 9;26(52):6894-900.

64. Geisbert TW, Daddario-DiCaprio KM, Williams KJ, Geisbert JB, Leung A, Feldmann F, et al. Recombinant vesicular stomatitis virus vector mediates postexposure protection against Sudan Ebola hemorrhagic fever in nonhuman primates. J Virol. 2008 Jun;82(11):5664-8.

65. Mire CE, Geisbert JB, Marzi A, Agans KN, Feldmann H, Geisbert TW. Vesicular stomatitis virusbased vaccines protect nonhuman primates against Bundibugyo ebolavirus. PLoS Negl Trop Dis. 2013; 7(12):e2600. 
66. Fauci. AS. NIAID Recognizes Significant Milestone in Ebola Vaccine Study. 2015 [updated 201507 Mayo 2015; cited 201509 Mayo]; Available from: http://www.niaid.nih.gov/news/newsreleases/2015/ Pages/PREVAILenrollment.aspx

67. Prevention CfDCa. Sierra Leone Trial to Introduce a Vaccine against Ebola (STRIVE). 2015 [updated 201514 Abril 2015; cited 201511 Mayo]; Available from: http://www.cdc.gov/vhf/ebola/strive/ index.html.

68. Bukreyev A, Rollin PE, Tate MK, Yang L, Zaki SR, Shieh WJ, et al. Successful topical respiratory tract immunization of primates against Ebola virus. J Virol. 2007 Jun;81(12):6379-88.

69. Warfield KL, Swenson DL, Olinger GG, Kalina WV, Aman MJ, Bavari S. Ebola virus-like particle-based vaccine protects nonhuman primates against lethal Ebola virus challenge. J Infect Dis. 2007 Nov 15;196 Suppl 2:S430-7.

70. Lee A, Agnelli G, Buller H, Ginsberg J, Heit J, Rote W, et al. Dose-response study of recombinant factor VIIa/tissue factor inhibitor recombinant nematode anticoagulant protein $\mathrm{c} 2$ in prevention of postoperative venous thromboembolism in patients undergoing total knee replacement. Circulation. 2001 Jul 3;104(1):74-8.

71. Fomivirsen approved for CMV retinitis: first antisense drug. AIDS Treat News. 1998 Sep 4(302):7.

72. Group TVS. A randomized controlled clinical trial of intravitreous fomivirsen for treatment of newly diagnosed peripheral cytomegalovirus retinitis in patients with AIDS. Am J Ophthalmol. 2002 Apr;133(4):467-74.

73. Schultheis B, Strumberg D, Santel A, Vank C, Gebhardt F, Keil O, et al. First-in-human phase I study of the liposomal RNA interference therapeutic Atu027 in patients with advanced solid tumors. J Clin Oncol. 2014 Dec 20;32(36):4141-8.

74. Geisbert TW, Hensley LE, Kagan E, Yu EZ, Geisbert JB, Daddario-DiCaprio K, et al. Postexposure protection of guinea pigs against a lethal ebola virus challenge is conferred by RNA interference. J Infect Dis. 2006 Jun 15;193(12):1650-7.

75. WHO. WHO Ebola MeetingBCX4430 Novel Broad-spectrum Direct-Acting Nucleoside Analogue IM or IV Administration. 2014 [updated 2014 4-5 Sectiembre 2014; cited 201508 Abril]; Available from: http:// files.shareholder.com/downloads/BCRX/0x0x779657/C0CA2634-C2D6-4875-9CBD-E5F4DC5D6899/ BCX4430\%20summary\%20slides\%20WHO\%20August\%2029\%202014\%20FINAL.pdf.

76. Smither SJ, Eastaugh LS, Steward JA, Nelson M, Lenk RP, Lever MS. Post-exposure efficacy of oral T-705 (Favipiravir) against inhalational Ebola virus infection in a mouse model. Antiviral Res. 2014 Apr;104:153-5.

77. Furuta Y, Gowen BB, Takahashi K, Shiraki K, Smee DF, Barnard DL. Favipiravir (T-705), a novel viral RNA polymerase inhibitor. Antiviral Res. 2013 Nov;100(2):446-54.

78. Bishop BM. Potential and emerging treatment options for Ebola virus disease. Ann Pharmacother. 2014 Feb;49(2):196-206.

79. ClinicalTrials.gov. An Open-Label, Multicenter Study of the Safety and Anti Viral Activity of Brincidofovir (BCV, CMX001) for Ebola Virus Disease. 2014 [updated 2014; cited 201508 Abril]; Available from: https://www.clinicaltrials.gov/ct2/show/NCT0227-1347

80. Parren PW, Geisbert TW, Maruyama T, Jahrling PB, Burton DR. Pre- and postexposure prophylaxis of Ebola virus infection in an animal model by passive transfer of a neutralizing human antibody. J Virol. 2002 Jun;76(12):6408-12.

81. Oswald WB, Geisbert TW, Davis KJ, Geisbert JB, Sullivan NJ, Jahrling PB, et al. Neutralizing antibody fails to impact the course of Ebola virus infection in monkeys. PLoS Pathog. 2007 Jan;3(1):e9.

82. Qiu X, Fernando L, Melito PL, Audet J, Feldmann H, Kobinger G, et al. Ebola GP-specific monoclonal antibodies protect mice and guinea pigs from lethal Ebola virus infection. PLoS Negl Trop Dis. 2012;6(3):e1575. 
83. Shedlock DJ, Bailey MA, Popernack PM, Cunningham JM, Burton DR, Sullivan NJ. Antibody-mediated neutralization of Ebola virus can occur by two distinct mechanisms. Virology. 2010 Jun 5;401(2):22835.

84. Pratt WD, Wang D, Nichols DK, Luo M, Woraratanadharm J, Dye JM, et al. Protection of nonhuman primates against two species of Ebola virus infection with a single complex adenovirus vector. Clin Vaccine Immunol. $2010 \mathrm{Apr} ; 17(4): 572-81$.

85. Ledgerwood JE, DeZure AD, Stanley DA, Novik L, Enama ME, Berkowitz NM, et al. Chimpanzee Adenovirus Vector Ebola Vaccine - Preliminary Report. N Engl J Med. 2014 Nov 26.

86. Rampling T, Ewer K, Bowyer G, Wright D, Imoukhuede EB, Payne R, et al. A Monovalent Chimpanzee Adenovirus Ebola Vaccine - Preliminary Report. N Engl J Med. 2015 Jan 28.

87. Ledgerwood JE, Costner P, Desai N, Holman L, Enama ME, Yamshchikov G, et al. A replication defective recombinant Ad5 vaccine expressing Ebola virus GP is safe and immunogenic in healthy adults. Vaccine. 2010 Dec 16;29(2):304-13.

88. Sullivan NJ, Geisbert TW, Geisbert JB, Xu L, Yang ZY, Roederer M, et al. Accelerated vaccination for Ebola virus haemorrhagic fever in non-human primates. Nature. 2003 Aug 7;424(6949):681-4.

89. Richardson JS, Abou MC, Tran KN, Kumar A, Sahai BM, Kobinger GP. Impact of systemic or mucosal immunity to adenovirus on Ad-based Ebola virus vaccine efficacy in guinea pigs. J Infect Dis. 2011 Nov;204 Suppl 3:S1032-42.

90. Zhu FC, Hou LH, Li JX, Wu SP, Liu P, Zhang GR, et al. Safety and immunogenicity of a novel recombinant adenovirus type- 5 vector-based Ebola vaccine in healthy adults in China: preliminary report of a randomised, double-blind, placebo-controlled, phase 1 trial. Lancet. 2015 Mar 24.

91. Martin JE, Sullivan NJ, Enama ME, Gordon IJ, Roederer M, Koup RA, et al. A DNA vaccine for Ebola virus is safe and immunogenic in a phase I clinical trial. Clin Vaccine Immunol. 2006 Nov;13(11):126777.

92. Dery M, Bausch DG. A DNA vaccine for the prevention of Ebola virus infection. Curr Opin Mol Ther. 2008 Jun;10(3):285-93.

93. Hensley LE, Mulangu S, Asiedu C, Johnson J, Honko AN, Stanley D, et al. Demonstration of crossprotective vaccine immunity against an emerging pathogenic Ebolavirus Species. PLoS Pathog. 2010 May;6(5):e1000904.

94. Sullivan NJ, Sanchez A, Rollin PE, Yang ZY, Nabel GJ. Development of a preventive vaccine for Ebola virus infection in primates. Nature. 2000 Nov 30;408(6812):605-9.

95. Geisbert TW, Bailey M, Geisbert JB, Asiedu C, Roederer M, Grazia-Pau M, et al. Vector choice determines immunogenicity and potency of genetic vaccines against Angola Marburg virus in nonhuman primates. J Virol. 2010 Oct; 84:10386-94.

96. Jones SM, Feldmann H, Stroher U, Geisbert JB, Fernando L, Grolla A, et al. Live attenuated recombinant vaccine protects nonhuman primates against Ebola and Marburg viruses. Nat Med. 2005 Jul;11(7):78690.

97. Qiu X, Fernando L, Alimonti JB, Melito PL, Feldmann F, Dick D, et al. Mucosal immunization of cynomolgus macaques with the VSVDeltaG/ZEBOVGP vaccine stimulates strong ebola GP-specific immune responses. PLoS One. 2009;4(5):e5547.

98. Mullard A. Experimental Ebola drugs enter the limelight. Lancet. 2014 Aug 23;384(9944):649.

99. Blaney JE, Marzi A, Willet M, Papaneri AB, Wirblich C, Feldmann F, et al. Antibody quality and protection from lethal Ebola virus challenge in nonhuman primates immunized with rabies virus based bivalent vaccine. PLoS Pathog. 2013;9(5):e1003389.

100. Blaney JE, Wirblich $C$, Papaneri $A B$, Johnson RF, Myers $C$, Juelich $T L$, et al. Inactivated or liveattenuated bivalent vaccines that confer protection against rabies and Ebola viruses. J Virol. 2011 Oct;85(20):10605-16. 
101. Papaneri AB, Wirblich C, Cann JA, Cooper K, Jahrling PB, Schnell MJ, et al. A replication-deficient rabies virus vaccine expressing Ebola virus glycoprotein is highly attenuated for neurovirulence. Virology. 2012 Dec 5;434(1):18-26.

102. Bukreyev A, Yang L, Zaki SR, Shieh WJ, Rollin PE, Murphy BR, et al. A single intranasal inoculation with a paramyxovirus-vectored vaccine protects guinea pigs against a lethal-dose Ebola virus challenge. J Virol. 2006 Mar;80(5):2267-79.

103. Ayithan N, Bradfute SB, Anthony SM, Stuthman KS, Bavari S, Bray M, et al. Virus-like particles activate type I interferon pathways to facilitate post-exposure protection against Ebola virus infection. PLoS One. 2015;10(2):e0118345.

104. Warfield KL, Dye JM, Wells JB, Unfer RC, Holtsberg FW, Shulenin S, et al. Homologous and heterologous protection of nonhuman primates by ebola and Sudan virus-like particles. PLoS One. 2015;10(3):e0118881. 